\title{
Mud shrimp burrows as dynamic traps and processors of tidal-flat materials
}

\author{
K. Kinoshita ${ }^{1}$, M. Wada ${ }^{2, *}$, K. Kogure ${ }^{2}$, T. Furota ${ }^{1}$ \\ ${ }^{1}$ Department of Biology, Faculty of Science, Toho University, Miyama 2-2-1, Funabashi, Chiba 274-8510, Japan \\ ${ }^{2}$ Ocean Research Institute, The University of Tokyo, Minamidai 1-15-1, Nakano, Tokyo 164-8639, Japan
}

\begin{abstract}
Bacterial abundance, electron transport system activity (ETSA) and organic matter content (total organic carbon [TOC], total nitrogen [TN] and chl a) on the burrow wall of the mud shrimp Upogebia major were determined and compared with those in surrounding non-burrow sediments and on the tidal-flat surface. The values of each parameter in burrow sediment tended to decrease outwardly from the wall, while bacteria abundance was highest in the subsurface of the burrow wall. In summer, the abundance of bacteria on the burrow wall was double that in the non-burrow sediments. In winter, both bacterial abundance and ETSA were at the same level as those in nonburrow sediments. The levels of TOC and TN on the burrow wall were more than 3 times higher than those in non-burrow sediments, regardless of the season. However, there was no significant difference in chl a content between burrow wall and non-burrow sediments. These results suggest that fresh organic matter in the burrow wall is supplied from the tidal-flat surface, making the burrow environment a suitable niche for microbial populations in the sediment. The mud shrimp burrow functions as a trap for organic matter and thus, helps prevent the outflow of carbon and nitrogen from the tidal flat.
\end{abstract}

KEY WORDS: Upogebia $\cdot$ Burrow $\cdot$ Bacteria $\cdot$ ETSA $\cdot$ Organic matter $\cdot$ Tidal flat

\section{INTRODUCTION}

Burrows of thalassinidean mud shrimps are one of the most significant structures in marine intertidal and shallow subtidal sediments. The burrows of shrimps of the genus Upogebia have a distinct U or Y (upper U-shaped part plus a lower I-shaped part) shape (Ott et al. 1976, Dworschak 1983, 1987, Scott et al. 1988, Griffis \& Suchanek 1991, Nickell \& Atkinson 1995, Coelho et al. 2000, Kinoshita 2002). The burrow of Upogebia major (De Haan) is Y-shaped, similar to those of other Upogebia species, and its lower I-shaped part can extend deeper than $2 \mathrm{~m}$ below the sediment surface (Hamano 1990, Kinoshita 2002). The U-shaped part of the burrow is ideal for efficient unidirectional water flow (Dworschak 1981, Allanson et al. 1992), which keeps the burrow wall oxidized and provides suitable conditions for aerobic bacterial metabolic activities, such as nitrification (Aller et al. 1983, Koike \& Mukai 1983).

*Corresponding author. Email: mwada@ori.u-tokyo.ac.jp
To understand the ecological significance of mud shrimp burrows in the coastal environment, we focused on Upogebia major, which is one of the major constituents of the macrobenthic community on tidal flats in Japan. We report here on bacterial abundance, electron transport system activity (ETSA) and organic matter content (total organic carbon [TOC], total nitrogen [TN] and chlorophyll a [chl a]) of the burrow wall sediment. Comparison of the values of these parameters on burrow walls with those in the surrounding non-burrow sediments revealed the role of $U$. major burrows in relation to microbial activity and the cycling of materials on tidal flats.

\section{MATERIALS AND METHODS}

Study site. A study site was chosen on a tidal flat in Shinhama Lagoon $\left(35^{\circ} 40^{\prime} \mathrm{N}, 139^{\circ} 56^{\prime} \mathrm{E}\right)$ near the head of Tokyo Bay, Japan (Fig. 1). The tidal flat is at

(C) Inter-Research $2003 \cdot$ www.int-res.com 


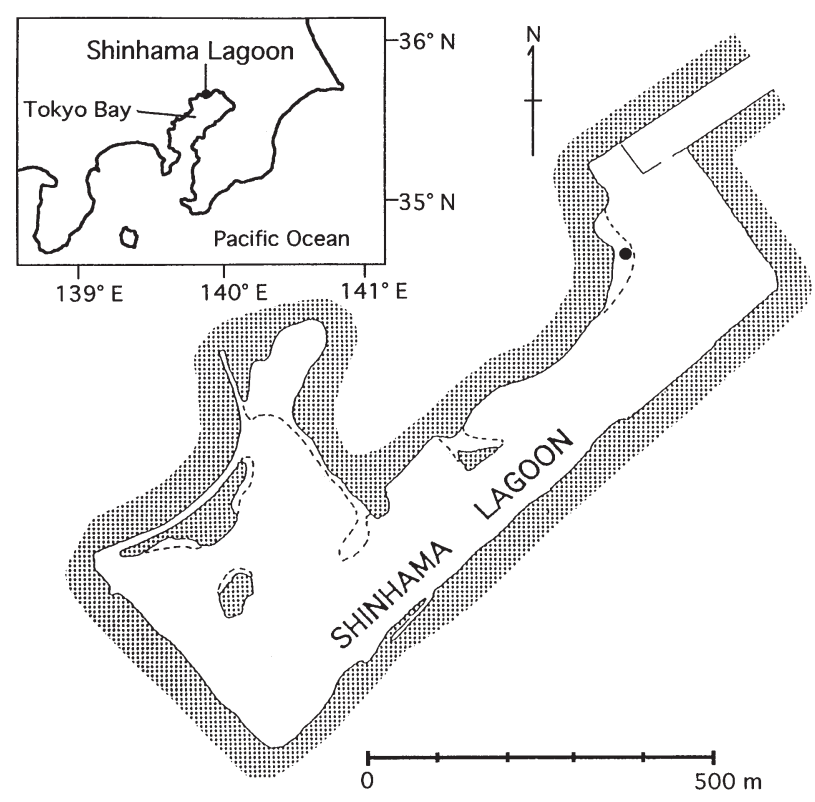

Fig. 1. Shinhama Lagoon and study site. Dotted lines show lowest tide line on the tidal flats

the northern end of the lagoon, where Upogebia major averages 36 shrimp $\mathrm{m}^{-2}$, with a maximum of 142 shrimp $\mathrm{m}^{-2}$ (K. Kinoshita unpubl.). The sediment of the flat consists of coarse mud containing about $60 \%$ silty clay.

Sampling procedure. Samples were taken on 2 occasions during the spring ebb tide, in January and July 2000. The dates were chosen to encompass a large range of environmental conditions. Temperatures on the surface and at a depth of $10 \mathrm{~cm}$ in the sediment were both $6.5^{\circ} \mathrm{C}$ in January (winter), and 33.0 and $29.0^{\circ} \mathrm{C}$, respectively, in July (summer).

Sediment cores including Upogebia burrows were taken by using a plastic pipe (inside diameter $10 \mathrm{~cm}$ ). Collected sediments were carefully sectioned to find the burrow walls of $U$. major down to a depth of $10 \mathrm{~cm}$. Subcores $1.5 \mathrm{~cm}$ long into the burrow wall were then taken using sterilized cut-off syringes (5 or $12 \mathrm{~mm}$ in diameter) (Fig. 2). The subcores were sliced into three $5 \mathrm{~mm}$ thick sections. Subcore samples were collected from 5 burrows. Two further sets of samples were taken from non-burrow sediments of the tidal flat (Fig. 2). These were collected at the surface and at depths of 1.5 and $10 \mathrm{~cm}$. Subcores from $1.5 \mathrm{~cm}$ depth were sliced into sections as described above. The $10 \mathrm{~cm}$-depth sediment samples were taken more than $5 \mathrm{~cm}$ from a burrow wall and in the present study, are referred to as standard sediment.

For counting bacteria, subcore samples were preserved in filtered (pore size, $0.22 \mu \mathrm{m}$ ) seawater with $2.5 \%$ glutaraldehyde immediately after sampling. All samples were kept on ice and transported to the laboratory within $3 \mathrm{~h}$ of the time of collection. In the laboratory, samples for counting bacteria were stored at $4^{\circ} \mathrm{C}$; the other samples were stored at $-80^{\circ} \mathrm{C}$.

Laboratory experiments. Subcores including intact burrow walls were kept in an aquarium (water volume $=50 \mathrm{l}$, water temperature $=20^{\circ} \mathrm{C}$ and salinity $=24$ ) in the dark with constant aeration. The top section of each subcore ( 0 to $5 \mathrm{~mm}$ ) was used to determine bacterial abundance, ETSA and organic matter content at 0 , 3 and $6 \mathrm{~d}$ of incubation ( $\mathrm{n}=5$ for each sampling date).

Analysis. Bacteria counting: To liberate the bacteria cells from sediment particles, Polysorbate 80 (Bacto Tween 80, DIFCO) was added to the sample with a final concentration of $1 \mathrm{mg} \mathrm{l}^{-1}$. After mixing for $1 \mathrm{~min}$, the sample was sonicated for $1 \mathrm{~min}$ and then mixed again for $1 \mathrm{~min}$. The suspended sample was centrifuged at $1600 \times g$ for $30 \mathrm{~s}$, and the supernatant was diluted 50-fold with filtered seawater. Then, $500 \mu \mathrm{l}$ of the supernatant was mixed with 4' 6-diamidino-2phenylindole (DAPI), with a final concentration of $5 \mu \mathrm{g}$ $\mathrm{ml}^{-1}$, and kept for $30 \mathrm{~min}$ at room temperature (ca. $25^{\circ} \mathrm{C}$ ). The filter was then placed on a glass slide and embedded in a non-fluorescent immersion oil. Bacteria cells were examined with an epifluorescent microscope (BH2-RFCA, OLYMPUS) with UV excitation. At least 200 single cells were counted on each slide at a magnification of $1250 \times$. Next, the sediment sample was centrifuged at $3000 \times g$ for $35 \mathrm{~min}$, and the precipitate dried at $110^{\circ} \mathrm{C}$ for $24 \mathrm{~h}$ to determine its dry

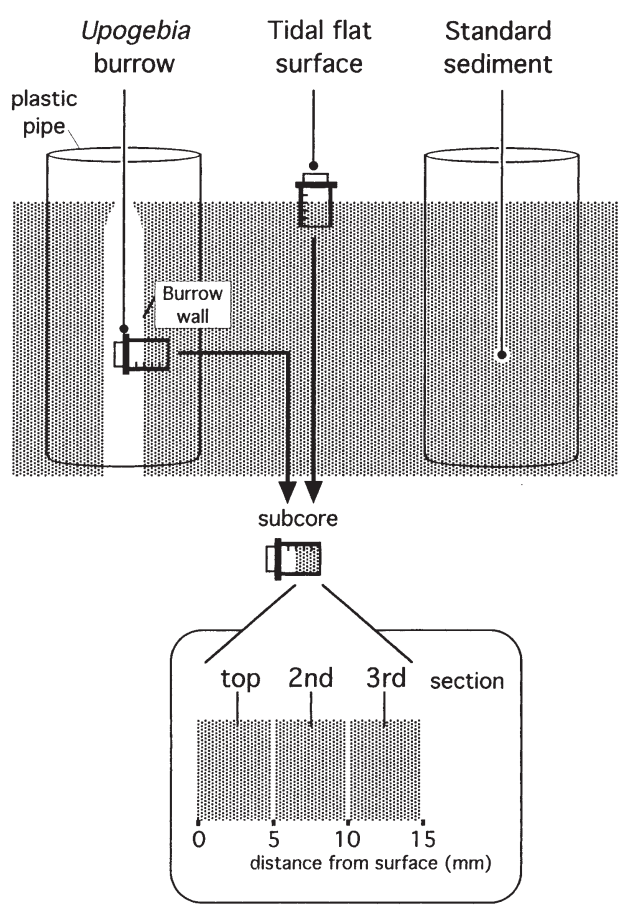

Fig. 2. Sediment sample locations 
weight. Bacterial abundance was expressed as cells $\mathrm{g}^{-1}$ dry sediment.

ETSA measurement: ETSA was measured by using the method of Broberg (1985) with slight modifications. One gram of wet sediment was mixed with $10 \mathrm{ml}$ of homogenization buffer $\left(25 \mu \mathrm{mol} \mathrm{MgSO}_{4} \cdot 7 \mathrm{H}_{2} \mathrm{O}, 0.5 \mathrm{mg}\right.$ PVP-40, $2 \mathrm{ml}$ Triton $\mathrm{X}$ and $0.01 \mathrm{~mol}$ EDTA in $1 \mathrm{l}$ of $0.1 \mathrm{M}$ phosphate buffer [pH 8]), and sonicated (TOMY UD-200, $22 \mathrm{~W}$ ) in an ice bath for $5 \mathrm{~min}$. This core mixture was clarified by centrifuging at $10000 \times g$ at $4^{\circ} \mathrm{C}$ for $10 \mathrm{~min}$, after which the supernatant was further clarified at $8000 \times g$ for $5 \mathrm{~min}$. We mixed $1 \mathrm{ml}$ of supernatant with $1 \mathrm{ml}$ of substrate solution $(7.6 \mathrm{~g}$ succinic acid sodium salt $2.1 \mathrm{mM}$ $\mathrm{NADH}, 0.15 \mathrm{mM}$ NADPH, $0.2 \%$ Triton $\mathrm{X}$ in $0.1 \mathrm{M}$ phosphate buffer), $0.5 \mathrm{ml}$ of $0.14 \%$ 2-(p-iodophenyl) 3 (p-nitrophenyl) 5 phenyl tetrazolium chloride (INT) solution and $1 \mathrm{ml}$ of homogenization buffer, and then incubated at $25^{\circ} \mathrm{C}$ for $40 \mathrm{~min}$. From a preliminary experiment, the concentrations of substrates described above were found to be sufficient to achieve $V_{\max }$ of the INT reduction with sediments used in the present study. Immediately after incubation, absorbance of the sample at $490 \mathrm{~nm}$ was read with a spectrophotometer (HITACHI U-3200). In calculating ETSA, the molar absorption coefficient of INT-formazan of $15.9 \mathrm{mM}^{-1} \mathrm{~cm}^{-1}$ (Kenner \& Ahmed 1975) was used. All ETSA values were determined within $3 \mathrm{~d}$ of field sampling.

TOC and TN contents: TOC and TN contents of the sediments were determined using a CHN analyzer (NA 1500, FISONS) with acetanilide (C $=71.09 \%, \mathrm{~N}=10.36 \%$ ) as a standard. Prior to analysis, sediment samples were treated with $1 \mathrm{~N} \mathrm{HCl}$ for $24 \mathrm{~h}$ to remove carbonates, and subsequently dried at $60^{\circ} \mathrm{C}$ in a vacuum to eliminate $\mathrm{HCl}$ vapors.

Chl a: A $100 \mathrm{mg}$ sediment sample was suspended in $5 \mathrm{ml} N, N^{\prime}$-dimethylformamide (DMF) and stored at $-20^{\circ} \mathrm{C}$ for more than $24 \mathrm{~h}$ before analysis. After being brought to room temperature (ca. $25^{\circ} \mathrm{C}$ ), samples were vortexed for $30 \mathrm{~s}$ and centrifuged at $3000 \times g$ for $35 \mathrm{~min}$. The clear supernatant was used to determine absorbance at 750, 663.8 and $646.8 \mathrm{~nm}$. Chl a concentrations were calculated from the equation given by Porra et al. (1989) and expressed as $\mathrm{mg} \mathrm{g}^{-1}$ dry wt.

Statistical analysis. Comparisons of bacteria abundance, ETSA and organic matter content of the burrow wall and the surrounding non-burrow sediments were made by using the MannWhitney $U$-test. Similar comparisons were made for the top section of the burrow wall and the standard sediment.

\section{RESULTS}

\section{Bacterial abundance, ETSA and organic matter contents in the burrow wall}

Profiles of microorganisms (bacteria abundance and ETSA) and organic matter (TOC, TN and chl a) in burrow wall cores are shown in Fig. 3A. All parameters, except numbers of bacteria, tended to decrease out-
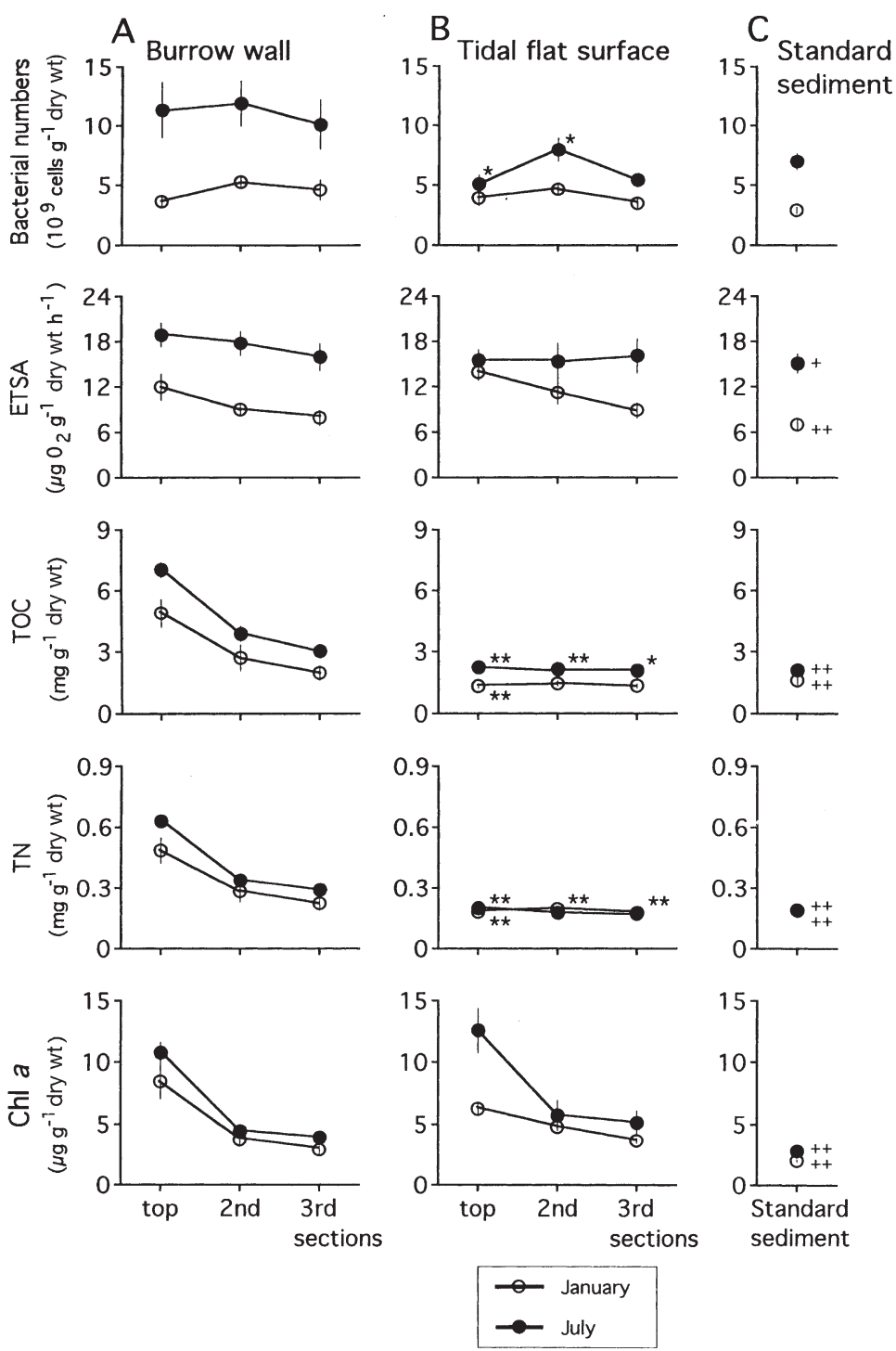

Fig. 3. Depth profiles of bacterial numbers, electron transport system activity (ETSA) and organic matter content (total organic carbon [TOC] total nitrogen [TN] and chl a) in subcores of the burrow wall (A), tidal flat surface (B) and standard sediment (C) in January and July 2000. Vertical bars indicate SE $(n=5)$. Significant differences between the burrow-wall variables and tidal-flat surface are indicated by ${ }^{* *} \mathrm{p}<0.01$, ${ }^{*} \mathrm{p}<0.05$ (Mann-Whitney $U$-test). Significant differences between the top section of the burrow wall variables and standard sediment are indicated by ${ }^{++} \mathrm{p}<0.01,{ }^{+} \mathrm{p}<0.05$ (Mann-Whitney $U$-test) 
wardly from the burrow wall surface and showed higher values in July (summer) than in January (winter). The numbers of bacteria peaked in the second section (5 to $10 \mathrm{~mm}$ ) rather than in the top one, although differences between the 2 sections were not statistically significant $(p>0.05)$. More than twice as many bacterial cells were found in summer $(1.13 \times$ $10^{10}$ cells $\mathrm{g}^{-1}$ dry wt sediment on average). ETSA ranged from $18.9 \mu \mathrm{g} \mathrm{O}_{2} \mathrm{~g}^{-1}$ dry wt sediment $\mathrm{h}^{-1}$ in the top section to $7.9 \mu \mathrm{g} \mathrm{O}_{2} \mathrm{~g}^{-1}$ dry wt sediment $\mathrm{h}^{-1}$ in the section farthest from the wall. ETSA values were higher in July by a factor of more than 1.5. TOC, TN and chl a levels declined most significantly between the top and second sections ( $p<0.05$ in January and $\mathrm{p}<0.01$ in July). The average $\mathrm{C}: \mathrm{N}$ ratio was $10.2 \pm$ $0.9 \mathrm{SD}$, and remained approximately constant regardless of the season and distance from the wall.
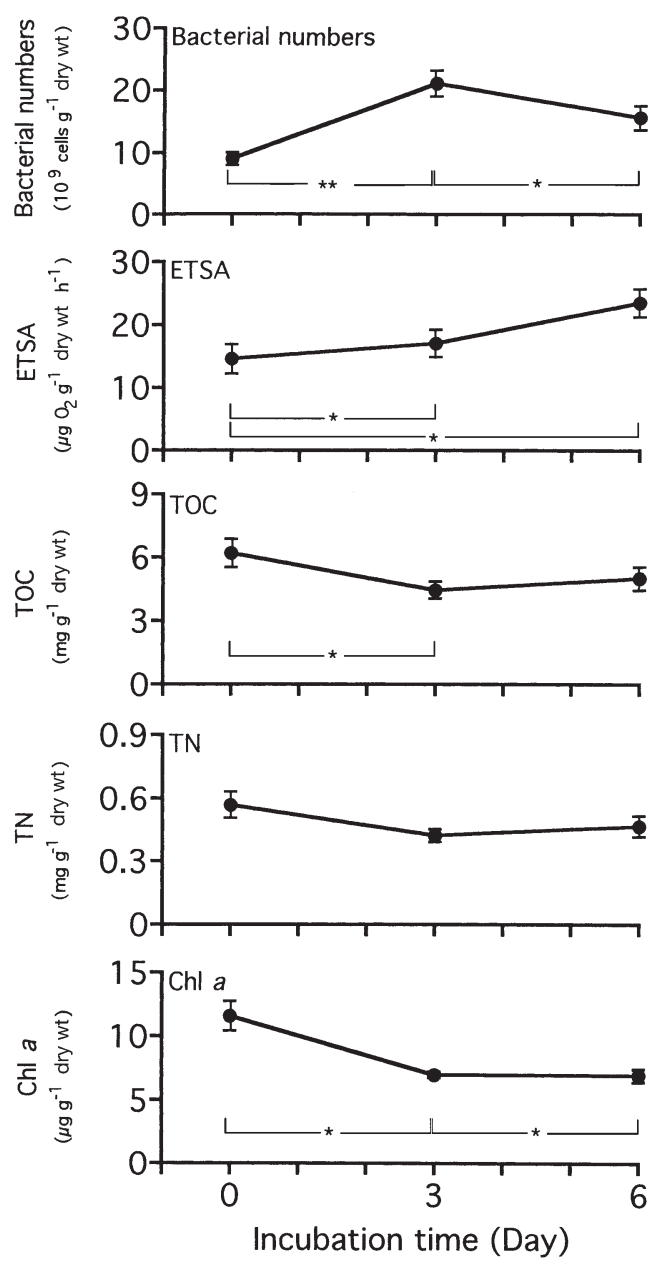

Fig. 4. Changes in bacterial numbers, electron transport system activity (ETSA) and organic matter levels in the top sections of the burrow subcores. Vertical bars indicate SE $(n=5)$. Significant differences among subcores on Days 0, 3 and 6 are indicated by ${ }^{* *} p<0.01,{ }^{*} p<0.05$ (Mann-Whitney $U$-test)

\section{Comparisons between burrow wall and non-burrow sediments}

Some differences between the burrow wall and tidal-flat surface were obvious (Fig. 3B,C). First, bacteria numbers in the burrow wall were nearly double those of the tidal-flat surface in summer ( $p<0.05)$, but were similar in winter. Second, TOC and TN accumulated in the inner 2 sections of the burrow wall, but were constant among sections of tidal-flat sediments ( $p<0.01)$. Chl a values were similar in the burrow wall and tidal-flat surface in both January and July.

Comparisons between the burrow wall and the standard sediment are shown in Fig. 3C. ETSA and organic matter in the top section of the burrow wall were clearly higher than those in the standard sediment. Levels of TOC, TN and chl $a$ in the burrow wall were 3-times higher than those in the standard sediment. Although the numbers of bacteria cells in the top burrow-wall section were not significantly different from those in the standard sediment, statistically higher numbers of bacteria were found in the second section of the burrow wall ( $\mathrm{p}<0.01)$.

\section{Changes in microbiological parameters and organic matter content under laboratory conditions}

Results of the laboratory experiments are shown in Fig. 4. Microbiological variables at 3 and $6 \mathrm{~d}$ incubation were higher than those at the beginning of incubation. Bacteria numbers increased by a factor of 2.3 in the first $3 \mathrm{~d}$, followed by a slight decrease to Day 6 . ETSA gradually increased to 1.6 times the initial value by Day 6 . In contrast, TOC, TN and chl a decreased by $40 \%$ in the first $3 \mathrm{~d}$.

\section{DISCUSSION}

\section{Burrow wall}

Upogebiids have been shown to draw large volumes of water through the U-part of their burrows (Dworschak 1981, Allanson et al. 1992). Thus, the burrow wall should be well oxygenated. The surface of the burrow walls was brown with a thickness of $1 \mathrm{~mm}$ and no iron sulfide was found in the sediment cores, indicating that the burrow and surrounding sediments were under oxidizing conditions. Thus, our data on bacterial abundance and ETSA in the burrow wall should reflect the aerobic metabolism of sediment microorganisms. Generally, ETSA represents the respiratory potential in all living microorganisms (Packard 1985), including autotrophic phytobenthos 
(mostly benthic diatoms), heterotrophic meiobenthos and microbenthos (protozoans and bacteria). Although the relative contribution of each biological component was not determined in the present study, autotrophic organisms do not seem to have been responsible for the ETSA. On the burrow wall, chl a levels in summer were similar to those in winter, while ETSA and bacteria numbers differed greatly between the 2 seasons (Fig. 3A). Furthermore, the laboratory experiments showed that, within a short period of incubation, chl a decreased, while both ETSA and bacterial abundance increased. These results strongly suggest that ETSA of the burrow wall was mainly derived from the activity of heterotrophic rather than autotrophic components. Autotrophic activities in the burrow environment would be limited by insufficient light.

The decrease in the chl a level to less than half of the initial value within $3 \mathrm{~d}$ of incubation indicates that chl $a$ in the burrow wall is a labile fraction of the organic matter. Chl a abundance in the burrow wall was comparable to that of the surface sediment, implying that the burrow of Upogebia major receives a continuous supply of fresh phytodebris. Microscopic observation revealed the presence of intact benthic diatoms (Navicula sp.) on both the burrow wall and the tidal-flat surface (Kinoshita pers. obs.). In addition, preliminary chromatographic analysis revealed that the pigment composition of the burrow wall was nearly the same as that of the tidal-flat surface and had several unknown peaks. It is most likely that the majority of chl a measured in the present study was derived from diatoms found in the tidal flat.

The increase in bacteria numbers, in contrast to the decrease in chl $a$, in the laboratory experiments strongly suggests that the phytodebris introduced into the burrow wall was used by bacteria. Population dynamics of the bacteria cells in situ may, however, be influenced not only by substrate, but also by other factors, including physical disturbance caused by the irrigation activity of Upogebia major and grazing pressure from eukaryotic microorganisms. Such organisms, nematodes and foraminifera, were found in the top section of the burrow wall. The lower bacterial abundance in the top section of the burrow wall, in contrast to the higher ETSA, may be attributed to predation on bacteria by coexisting microorganisms.

\section{Comparison between the burrow wall and tidal-flat surface sediment}

Bacteria numbers and ETSA in the burrow wall were comparable to those of the surface sediment in winter, whereas in summer, their levels in the burrow wall were up to 4-times higher than those in the surface sediment. This seasonal difference suggests that temperature has a substantial impact on microbial biomass and metabolism on the burrow wall. On the tidal-flat surface, however, there were fewer significant differences in the microbiological parameters between the 2 seasons, suggesting that factors other than temperature have a greater effect on microbiological processes.

The constant distribution of TOC and TN in the tidalflat sediment implies that the surface sediment is well mixed by physical and/or biological disturbance. Physical disturbance, particularly water movement, may erode the tidal-flat surface, resulting in less accumulation of organic matter in the sediment. This assumption is supported by our preliminary experiment that showed approximately $0.9 \mathrm{~g}$ of sediment particles were trapped at the present study site in a $9 \mathrm{~mm}$ diameter, artificial burrow tube within $1 \mathrm{~h}$ (data not shown). Thus, it is likely that sediment of the tidal-flat surface is in a substrate- (organic carbon and nitrogen) limited condition because physical disturbance has restricted the abundance and activities of microorganisms. Taking all these factors into account, Upogebia burrows can be viewed as a trap for benthic primary production and organic matter that would otherwise be washed out of the tidal flat by erosion. The present results are in good agreement with other reports on the accumulation of phytopigments and organic matter in biogenic structures in the sediment (Suchanek 1983, Takeda \& Kurihara 1987, Dobbs \& Guckert 1988, Dworschak \& Ott 1993, Felder \& Griffis 1994).

\section{Turnover time of TOC in the burrow wall}

The results of our laboratory experiments were used to estimate the turnover time of organic matter in burrow sediment. Assuming that the decrease in TOC in the burrow wall after $6 \mathrm{~d}$ was balanced by the increase in ETSA (Fig. 4), the reduction of TOC (RT) could be expressed by the formula RT $=0.39 \times$ ETSA. The time required for TOC in the wall to reach the level in the standard sediment in winter and summer (Fig. 3C) was calculated to be 29 and 28 d, respectively. These values might be underestimates as the decomposition rate may decrease as the labile fraction of organic matter becomes smaller.

\section{CONCLUSION}

The burrow of Upogebia major has higher bacterial abundance and ETSA than the surrounding non-burrow sediments. The burrow accumulates considerable organic carbon and nitrogen, probably derived from 
the tidal-flat surface. Fresh phytodetritus forms the labile fraction of the organic matter and is likely to be efficiently utilized by bacterial populations in the burrow wall sediment. As a consequence, the burrow wall of the mud shrimp provides a suitable niche for heterotrophic microorganisms. Thus, the burrow functions as a trap for organic matter, reducing outflow of carbon and nitrogen from the tidal flat.

Acknowledgements. The authors thank the following for their superb cooperation, without which this project and manuscript could never have been realized. Drs. T. Miyajima, H. Urakawa, A. Shibata, R. Fukuda and M. Shimanaga offered useful suggestions on bacteria counting, chl a and CHN analyses, and sediment sampling. Mr. S. Arita assisted in the field observations. Dr. Y. Hasuo and Ms. S. Hasuo, superintendents of Gyotoku Bird Sanctuary, provided the opportunity to use the field site. We also thank the editor and reviewers for their valuable comments to improve the manuscript. This study was also supported by Grants-in-Aid for Scientific Research, No. 0856093, and Creative Basic Research, No. 12NP0201 (Dynamics of the Ocean Biosystem, DOBIS) of the Ministry of Education, Culture, Sports, Science and Technology (MEXT), Japan.

\section{LITERATURE CITED}

Allanson BR, Skinner D, Imberger J (1992) Flow in prawn burrows. Estuar Coast Shelf Sci 35:253-266

Aller RC, Yingst JY, Ullman WJ (1983) Comparative biogeochemistry of water in intertidal Onuphis (Polychaeta) and Upogebia (Crustacea) burrows: temporal patterns and causes. J Mar Res 41:571-604

Broberg A (1985) A modified method for studies of electron transport system activity in freshwater sediments. Hydrobiologia 120:181-187

Coelho VR, Cooper RA, Rodrigues SA (2000) Burrow morphology and behavior of the mud shrimp Upogebia omissa (Decapoda: Thalassinidea: Upogebiidae). Mar Ecol Prog Ser 200:229-240

Dobbs FC, Guckert JB (1988) Callianassa trilobata (Crustacea: Thalassinidea) influences abundance of meiofauna and biomass, composition, and physiologic state of microbial communities within its burrow. Mar Ecol Prog Ser 45: 69-79

Dworschak PC (1981) The pumping rates of the burrowing shrimp Upogebia pusilla (Petagna) (Decapoda: Thalassinidea). J Exp Mar Biol Ecol 52:25-35

Dworschak PC (1983) The biology of Upogebia pusilla (Petagna) (Decapoda, Thalassinidea): I. The burrows. PSZN I: Mar Ecol 4:19-43

Dworschak PC (1987) Feeding behaviour of Upogebia pusilla

Editorial responsibility: Otto Kinne (Editor),

Oldendorf/Luhe, Germany and Callianassa tyrrhena (Crustacea, Decapoda, Thalassinidea). Invest Pesq 51:421-429

Dworschak PC, Ott JA (1993) Decapod burrows in mangrovechannel and back-reef environments at the Atlantic Barrier Reef, Belize. Ichnos 2:277-290

Felder DL, Griffis RB (1994) Dominant infaunal communities at risk in shoreline habitats: burrowing thalassinid Crustacea. OCS Study \#MMS 94-0007. US Dept Interior Minerals Management Service Gulf of Mexico OCS Regional Office, New Orleans, LA, p 87

Griffis RB, Suchanek TH (1991) A model of burrow architecture and trophic modes in thalassinidean shrimp (Decapoda: Thalassinidea). Mar Ecol Prog Ser 79:171-183

Hamano T (1990) How to make casts of the burrows of benthic animals with polyester resin. Benthos Res 39:15-19 (in Japanese with English abstract)

Kenner RA, Ahmed SI (1975) Measurements of electron transport activities in marine phytoplankton. Mar Biol 33: $119-127$

Kinoshita K (2002) Burrow structure of the mud shrimp Upogebia major (Decapoda: Thalassinidea: Upogebiidae). J Crustac Biol 22:474-480

Koike I, Mukai H (1983) Oxygen and inorganic nitrogen contents and fluxes in burrows of the shrimps Callianassa japonica and Upogebia major. Mar Ecol Prog Ser 12: 185-190

Nickell LA, Atkinson RJA (1995) Functional morphology of burrows and trophic modes of three thalassinidean shrimp species, and a new approach to the classification of thalassinidean burrow morphology. Mar Ecol Prog Ser 128: 181-197

Ott JA, Fuchs B, Fuchs R, Malasek A (1976) Observations on the biology of Callianassa stebbingi Borrodaille and Upogebia littoralis Risso and their effect upon the sediment. Senckenb Marit 8:61-79

Packard TT (1985) Measurement of electron transport activity of microplankton. In: Jannasch HW, Williams PJL (eds) Advances in aquatic microbiology, Vol 3. Academic Press, London, 207-261

Porra RJ, Thompson WA, Kriedemann PE (1989) Determination of accurate extinction coefficients and simultaneous equations for assaying chlorophylls $a$ and $b$ extracted with 4 different solvents: verification of the concentration of chlorophyll standards by atomic absorption spectroscopy. Biochim Biophys Acta 975:384-394

Scott PJB, Reiswing HM, Marcotte BM (1988) Ecology, functional morphology, behavior, and feeding in coral- and sponge-boring species of Upogebia (Crustacea: Decapoda: Thalassinidea). Can J Zool 66:483-495

Suchanek TH (1983) Control of seagrass communities and sediment distribution by Callianassa (Crustacea, Thalassinidea) bioturbation. J Mar Res 41:281-298

Takeda S, Kurihara Y (1987) The effects of burrowing of Helice tridens (De Haan) on the soil of a salt-marsh habitat. J Exp Mar Biol Ecol 113:79-89

Submitted: January 14, 2002; Accepted: September 17, 2002 Proofs received from author(s): January 6, 2003 